\title{
Tur Family in Shahname
}

\author{
Susan Fotoohi \\ Faculty Member, Farhangyan University, Bent al-Hoda Sadr Pardis, Sanandaj, Iran \\ E-mail address: slider1388@yahoo.com
}

\begin{abstract}
In Shahname, Turanian has been regard as the opposite side of Iranians (Iraj's Family). Ferdowsi has been devoted the main part of his masterpiece, Shahname, in to the dispute between these two family. In this paper, Tur story, their family and the causes of their dispute are take into consideration then, in a comprehensible manner, Tur family members, the meaning of their names, psychological characteristics wars and their genealogy are studied.
\end{abstract}

Keywords: Iran; Turan; Iranians; Ferdowsi; shahname

\section{INTRODUCTION}

One of the most strengthened and glorious literary works remaining from human culture is Abulghasim Ferdosi's Shahname. Shahname not only is an epic work dealing with the kings adventures, but also is considered as a marvelous world with various good and bad manifestations of human deeds during their life. One can adjust this masterpiece and its event with the realities of his her life.

Actually Ferdowsi, as a skillful psychologist, has the complete familiarity with human pain and mental obsession. So, in their definition and explanation he has enjoyed from allegory and created the war and dispute stories between Iran and Turan sides. He considers Iran and Turan as good and bad symbol, relatively. In explaining Turan side, he has considered indecent characteristics of human and their painful exclusion.

In the literature as mentioned some bad characteristics such as greed, avarice, malevolence, jealousy, deceitfulness, light - mildness, oppression and ... have been studied according Turan family, their characteristics and the meaning of their name. of course in every side, this great literary work manifest various important and power point about each aspect of human life so, it is necessary to search in this great literary work in order to reach the human maker learnings and meanings.

About Tur family, as an opposite side of Iraj, one may think these two families have different race, but both are from faraidauns antecedents. Both are Irani and Aryan.

The difference / distinction between two families relates to the way in which tur and Iraj authorities have adopted. Iraj follows the intimacy and friendship path, while tur takes the path of enmity.

Ferdowsi has created the war between Iran and Turan to depict the frontier between good and bad and the real face of these two elements in front of human eyes and direct them into their own way. 
Of course, Ferdowsi does not consider Turanians as bad humans but he depicts the bad view from Iranian point of view. He believes the greed and jealousy are the source of the badness /evil in the entire human without exception. In the first stage wars between Iran and Turan, mean till Goshtasb era, Turan start the war and Turan are defeated. And in Goshtasb era, Iran start the war and defeat Turan, But in other eras Iran are defeated in which yazdgerd and sassanian king are killed by bijan. So, Ferdowsi, based on proportional tendency regarding good and bad thoughts, can solve the opposition between mythological faith in believing in to the option / free will as a main component of his sectarian thoughts. He considers Turan as turks to protest in the rulings government (Ghaznavian) which is a stranger government with Iranian custom. And, as a result, his precious literary work is not accepted by Ghaznavid king. Ferdowsi declare his un-bias attitude in his great verses, such that he regards some Turan authorities such as Aghriras and even Afrasiab in some characteristics more precious than Iranian one. From Ferdowsis point of view nobody is complete, because he declares:

Everybody has weak points whether in secret or obviously. Kavous never presented in the war field, but Afrasiab, the king presented in the wars strictly, so, he praises Afrasiab because of his braveness Mountain would be melt as fluid as water, if it hears Afrasibab's name.

\section{A COMPLETE WORK ABOUT TURAN AND TURANIAN}

Turan is a noun in determining the regions located in east-north of Iran. Ihe name belongs to an era before the middle era of Iran history. The word Turan and turk has repeated 400 times in shahname.

Iraj \& Salm and Tur were fereidun's sons. They named their authority region based on their own name. Meanwhile, there is scientific reason in which Turan are regarded as the residents of ancient Iran. The name of Som Turan authorities have been mentioned in Avesta, zartosht's holy book. All the names are Aryan and their meanings are clear-so considering ottomans and turks as Aryan turan is falce.

What is Aryan? A group of people lived in a region named Ariavarta before migrating into Iran plato and they were shepherd. Aryan means those who keep livestock, Because of Altai tribes pressure, they migrated into Iran Plato and named it Airyana which means Aryans territory. Today this region is called Iran. After migrating in to Iran, Aryans divided into two main parts. One part, Iranian, adopted civic life, Iranian occupation was agriculture, animal husbandry and pomading. They became Turan enemy (lived in oxus, jaxartes and the north of Caspian sea). Turan named their region twiryana means Tur.

\section{TURAN IN MYTHOLOGICAL GEOGRAPHY}

In shahname, Iran and Turan are regarded as two symbols. In mythological geography we should search these two symbolic regions. Iran is the symbol of innocence, brightness and justice. The priority in power and physiological abilities belongs to Iraninas so, Turan, the most powerful one, never equals Iranians (shahname. Vol.3, verse. 58-1347). 


\section{THE SURVEY OF TUR FAMILY MEMBERS}

Based on shahname's stories, Tur Family members are 39 person including: Arjasp, Espanoi, Roieen, zadashm, sepehram, shide, Farangis, Fereidun, Gharakhan, krukhan, kelbad, kahrom kahila, kaixosro, garsivaz, Gavegordgir, Goroy, lahak, Farshidvard, siavash's mother, manije, Nastihan, vaise, and Human.

Arjasp: In shahname, he his Turan's king and Afrasiab's grandchild. In Avesta it means having a presious hourse (AR) ATASPA). (Ferdowsi' shahname, P.234). In Avesta, Arjasp is Afrasiab's nephew (Yashtha, p,273, vol.2). In Iatekar zariran poem. The story of this veligious war with Arjasp, because of propaqating zartosht religion, has been explained completely (Ideal Human, p.92). And a great part of shahname has been devoted into iatkar zariran's wars with Arhasp and Esfandiar.

Espanoi: In national myths, Espanoi, was the name of tezhav bond maid / slave girl, Afrasyab's groom. She was a very beautiful maid, and because of Tezhav running from the battle field, Bijan- Giv's sun, became her owner (Mosahab Bibliography, vol. 1, p. 121). In shahname there is no exact evidence she is Afrasyab's doughter. But KaiXosro's insistence about bringing Espanoi into Iran proves these criteria. Espanoi, in Shahname, is regarded as one of the most famous and beautiful women (research in shahname, p. 138-139).

Agriras: It is a noun compounded of two part, Agriras means precursor and Rasa means wheel. So, Agriras Can be translated the person whose wheel moves ahead. In Avesta, Such as shahname, Agriras is regarded as one of the good. In spite of his brother's view, Afrasyab, he searchs for peace. Such as Iraj who was killed by his brother (Tur), Agriras was killed by Afrasyab. These two murdered men had similar views in the way/ path of humanity.

Afrasyab (Father): Afrasyab is the name of Turan King which means wayfarer/hiker (Dehkhoda Bibliography). Based on Shahname says Afrasyab's Avestaic name is Frengersin (Yashtha, vol. 1, p. 207). For Afrasyab, War is a passway accompanied the last year of his kingdom with heroism through passing war. He liked heroism more than kingdom (From the Flower color Till Thorn pain, p. 379). In Shahname, It has mentioned the main foundation of Afrasyab attack into Iran is originated from two inevitable realities. The first one is Rav's pride and overambition. The other one is his great aegerness to take his ancestors vengeance, "Tur". Ferdowsi compare the brave behavior of Afrasyab with the Calm soul of his ancestor "zadashm" which never take an aggressive action toward Iranians (The Researchs in shahname, p. 248). In the most wars, Afrasyab afraids from Rustam's existence After killing the Siavash by Afrasyab, in Kaikavous era, the first revenge war of Iranian was started by Rustam's Command against Afrasyab. Finally, After several wars by his grandchild, Kaixosro was killed by Rustam in response to Siavash's death. As we know, after seeking asylum of Siavash into Turan, he got married with Farangis, afrasyab's daughter. After a while Garsivaz envies of siavash situation. So Garsivaz make the situatuin so bad Afrasyab decides to kill Siavash. In Siavash story, his role/face is more ugly than his other roles. He is a suspicious King such that Garsiaz's malevolent offects his soul. He fears from a powerful figure as his enemy. So, he considers siavash as the figure he had depicted in his thoughts.

Afrasyab (Son): In some versions of Shahname including Jul press, He is the fourth son of Afrasyab, wich in the big/great war of Kaixosro with Afrasyab, he was the commander of the thousands Turks and Kept safe his brother, pashing, behind the war trench. In Hamidian version instead of Afrasyab, Gharakhan has been mentioned (Shahname's names culture, p. 115). 
Endariman: In Hyrcanian, this name has been recorded as Endarman which is Afrasyab's brothere but in zariran yadegar and Avesta, Endriman is Arjasp's brother. In shahname, instead of vandariman as its Avestian version it is Endriman or Enderiman (yashtha, vol. 1, p. 239) this hero and his fellow, kahrom, were hanged, after Arjasp was killed in Esfandiar attack into Roien Castel, On the castle door (shahname, Hamidian, vol.6, verses 689-749).

Ila: In Shahname he is Afrasyab's grandchild, In holly book Ghamus means the trees. Also, it is the name of a famous city and four authorities of Jews (Shahname names culture, P-145).

Barman: In Shahname, there are two heroes with the name of Barman with both of them are Turan. The first hero lived in Nowzar, Vaise's son and Piran's brother, era- The second lived in Kavous era. Barman means a person who has a great Soul- And in Shahname comprehensive culture, it means "worthy". Barman is a powerful choice of Turan side.Barman is the symbol of one who seeks the power and name.

Pashang: Pashang is Zadsham's son, Afrastab's father and piran vaise's brother. After Zadashm, he is one of Turan Kings. The first war between Iran and Turan occurd in pashang's era. He is a revengeful / vengeful person and wants to attack Iran. He applies the smallest weak point to attack Iranian. After Manuhehr deas and nowzar'sthrone disturbance, he campaigned into Iran. He was an opportunist hero (Shahname Overview/162-163)

Pilsom: Pilsom is a great hero from Turan and the Smallest brother of Piran killed in Sorkhe revenge war. He was powerful as same as Rustam. It means the horse with thick hoof. Also, It means one who has powerful feet and destroy his enemy under his feet (Shahname names culture, p.271-279). Pilosm liked siavash and asked Afrasyab to pardon Siavash.

Tur: Tur means hero and in Persian culture it means brave and valiant. Because Turan was Iranian's enemy, from Iranians point of view it means mad and Savage. Tur is one of Fereidun's Childs and Iraj \& Salm's brother. From his mother Tur and Salm are Shahrnaz's sons and Iraj is Arnavaz's son. After Feredun hears their faith from astronomers, divides the world amoung them . he gave Rom and Mesopotamia to Salm, China and Tukestan to Tur and Iran and Naizevaran region to Iraj. But, he examines his sons to clear his suspicion. Fereidun named them in accordance with their reaction. Their reaction shows their mental characteristics for Fereidun. Salm wase bad-hearted, Jealous and timid person which never risk's Tur was a hottempered, incautious and furios person. Iraj was a brave, truthful and kind person. Salm and Tur think their father oppresses them about the regions divided among these three brothers.

Jarire: Jarire is piran vaise's daughter, Farud's mother and siavash's wife. In heroic era, Jarire is the first one who suicide. In shahname the only woman who bent her waist under disappointment experience is Jarire. When she became Siavash's wife, she was a child. She beared Farud without Siavash Supportion. When she wrote their child birth for Siavash, She ordered to print their child foot print to prove Siavash She had the fertility power in spite of her Childness, It shows her Carefulness. In Shahname, union in marriage is the most strong union. And husband has the priority on the other affairs. Jarire and Farangis show are two manifestation of this union. Observing the death of his young son by Tuss is the main cause of her death, because after Siavash death the only motivation in her life is Farud, her son. So, she suicides.

Jahn: Jahn is Afrasyab's son, which is a smaller than shied. He is father's Consul ant. He was one of the famous Iranian Kings. Ferdowsi considers Jahn as Afrasyab's throne (shahname, mol, vol. 4, verse 1370). 
Damur: Damur is one of Afrasyab's relatives. This word in Turkish language means iron (Shahname names culture). He is a Jealous and bad - hearted person who encourage Afrasyab to kill Siavash ( shahname, Hamidian, vol. 3, verse. 2278).

Roien: In Shahname, It is the name of piran vaise's Son. Such as other members of Tur family he took actions whether in war or peace, At least he was killed by Bigan in davazdah rokhs war.

Zadashm: He is Pashang's father and also he is Turan king in Manuchehr's era. Zadasham was in peace with Iranian. Because of this attitude, Afrasyab critisized zadashm. But Aghriras praised. Zadashm and beware Afrasyab and Pashang from war with Iranian.

Sepahram: Sepahram is a Turan braveman. He is relative and leader of Afrasyab troop in attacking with kavous troop (shahname names Culture, P.541). In Shahname there is no evidence with show Sepahram relationship /kinship with Afrasyab. He was killed in Yazdah Rokh war by Hajir Gudarz.

Sorxe: Sorxe is one of Afrasyab's son. He participated in a Campaign of Iranian to revenge Siavash by his father command. Afrasyab orders to separate Faramarz head from his body. But, in his war Sorxe is defended by Faramarz. There Rustam orders to tie his hands, Because of Siavash death, and cut his head in a basin and then hang his body and rent it.

Shide: shide means the light things and the sun. He is Afrasyab's son- Because he had a handsome figure, he was called shide. In shahname, he sometimes is called "pashang". (Name Culture/697). Tabari writes: Shide had such fearful powers all Iranian troop harassed from shide (Research in shahname /140). In the important affairs in which the enemy should know nothing, Afrasyab consulted with Shide, his son- At least in a war between shide and kaixosro, Shide's nephew, he is defeated andkilled by Kaixsoro. Kiaxosro became upset and ordered to bury Shide's body in xosrovani's grave and wash his body with ambergris and musk and respect his grave.

Farangis: Zabih Olah Safa believes: "the name of Farangis in Pahlavi and Sanskrit resource is known as Vispanfrya (Epic in Iran /633). Farangis is one of afrasiab's daughter farangis became Siavash's wife by Piran's suggestion. Farangis is one of the most offenced woman in Persian literature. During the war she remains loyal to husband and shows her sympathy in siavash murder. She is kaixosor's mother, one of the precious figure in Shahname. Said that from the morality affair, she has an upper place than Turan.

Fereidun: In Pahlavi, it is Fartan and one of pishdad Kings (shahname Comprensible culture, p.752). IN Avesta Fereidun is called Thraetaona in which the first part " Than" means the number three and the secons part "Thra" etoona" means Aidun, Fereidun, "Seidun" These such three (Turanian from the history Morning till Islan Acceptance, P.19-20). In national stories, his father's name is Abtin, the son of Tahmuras, (Masahab's bibliography, vol. 1, p. 43). Abtin was Killed by Zahhak. Fereidun's mother is Faranak. Faranak gave Fereidun a meadow guard (ian) to rear him with the milk of barmaye, a famous Calf in shahname. He had two brothers named kyanosh and pormaye and three Childs with untitled names. (shahname, jul mol, vol. 1, verses 29-219). 


\section{FEREIDUN'S FAME IS BASED ON THE FOLLOWING}

1- from the race originality which is honor for others to be appointed in him. 2- having glory and spledour. 3- prevailing on Zahhak. 4- passing from Arvand River without ship to open Zahhak's capital. 5- building Kaviani's banner. 6- dividing the world among his sons. 7mourning from child's death. 8- building Gavsar Gors. 9- wisdom. 10- theism and heroism. 11- his family adventure as a part of the battle between good and bad. This battle is kept in all the heroic era of Shahname. It has two stages. The first one begins with Iraj's death and the other begins with Siavash's death. (Heros Life and Death in Shahname, p. 149). In Shahname, Fereidun is the symbol of good deeds but with dividing the world among his sons, he brings the bad and good into the world. So, the governing attitudes in Shahname is summarized in his performances.

Gharakhan: Gharakhan is the forth son of Afrasyab. He was the troop ministry (Shahname Names Culture / 747). In attitude, figure, and physical characteristics, he was similar to his father.

Krukhan: Krukhan is Vaise's son. In Shahname he is called Krukhan Vaise Nejad (Vaise race). And in Shahname comprehensible culture, it is considered as his brother or son's name (Comprehensible Bibliography / 812).

Kelbad: in Shahname Kelbad is the name of two different persons in two different eras. One of them is Gulbad, one of Piran Vaise's brother killed by Zal, a Turan hero. The other one was killed by Faribourz in Kaixosro's era in Davazdah Rokh War.

Kahrom: Kahrom is one of the Turan heros in Arjasp's era. Sometimes he is called as Arjasp's brother and sometimes as his son. In the last war of Goshtasp and Arjasp, after Arjasp was killed by Esfandiar, he was prisoned and hanged by Esfandiar ( Epic in Iran/626- 627)

Kahila: Kahira is Afrasyab's grandchild. After Piran was killed, Afrasyab arranges a new troop to attack with Kaixosro and in this war the various group commands was given into the grand child by Afrasyab. Kahila was killed by an Iranian hero known as Manuchehr (Shahname, Jul Mul, vol. 4, verses 325-393 \& 805-806).

Kaixosro: Kaixosro in Greece language is Xosroes and in Sanskrit is Seosvasa. In Avesta, Xosro is Haosravah. It means a person who has a good reputation, good- hearted (Yashtha, vol. 2, p. 205-256) Because of his name in Vider Veda's book of Indians, one can say Xosro was one of the great Iranian and Hindus authority before separating Indians from Iranians. Kaixosro is the result of Farangis and Siavash's marriage. After his father death, Siavash entered his first step into the universe. Afrasyab sends Kaixosro and his mother into Khotan because of enemies fear. Finally Giv finds Kaixosro and returns him into Iran. After reaching the kingdom, he wins Afrasyab in his father revenge. The end of Kaixoso's life is a tragedy. He become disappointed and gives his kingdom to Lohrasb. Then in a mysterious manner he becomes hidden. Ferdowsi's spaces for searching the adventures are full of Sufism.

Garsivaz: he is Afrasyab's brother and Pashang's son in Shahname. He is Afrasyabs consultant. He is the guardian of Afrasyab's throne. Siavash's mother has introduced himself as Garsivaz's relative. In Avesta, Garsivaz means endurance and stability. He had a main role in Siavash's death. So, he has regarded as the evil. After Afrasyab was killed by Kaixosro. Kaixosro's attendants bring Grisiuz into Kaixosro's alter. Then he orders to cut his body in two equal parts (Tur Family in Shahname, A. M thesis, P. 184-191). 
Gavegordgir: Gavegordgir is the Fifth Childs of Afrasyab in war With Kaixosro, Maimane with30 thousand horse man is given to him (shahname / 3/32b).

Goroy: Tabari and Balami Know Goroy as pashangs Son. Borhan Consider Goroy as AFrasyab's relatives. While Ferdowsi Knows him as Zereh's son (shahname names Bibliography, p. 878). Goroy has a jealousand bad - hearted character. He is the main figure in siavash's death. Finally Goroy is killed By Giw in Davazdah RoKh's war ( Shahname, jul mul, verses 2495-2529).

Lahak and FarshidVard : Lahak is piran vaise's brother. Lahak and Farshidvard: lahak is piran vaise's brother. In other shahname version his name has been written as lahak and kahal. Farshidvard means bright. In AVesta it is "Faras ham vareta" and in Pahlavi it is Farshvart. (Shahname Name Biblig raphy, P. 622-959)

Manije: Manije is one of Afrasyab's Daughter. She Such as Farangis, had Iranian husband. She Flies into Iran as Farangis. She Flies into Iran her husband Bijan, Giv's son. A great War Starts when manije Flies into Iran. This war cause AFrasya's throne life ends.

Nastihan: Nastihan is piran vaise's Son and piran's brother such as his brother, he was under service of AFrasyab . (shahname, jul mpl, v. 2. 83).

Vaise: vaise is pashang's brother and turan's major general. In Avesta, the name of vais's family exist, and it is founder is called Ask (Epic in Iran / 628). In Shahname, vaise attends in Afrasyab's war with Nowzar alone. In this war Afrayab encourage vaise to kill Gharan, because he killed Barman (Afrasyab's Son). Vaise's enclusion is unclear (Shahname, Hamidian, 1995).

Human: Human is the derivation of (HAoMA) HoM and its general pronunciation is Human, this name has two part. The part one means good and the second part means soul. Human means a person who has good Soul. (Shahname name Bibliography, p. 1120-1121). Human is one of vaise' S son and A Frasyab's cousin. His brothers are Piran, Barman, lahak, Farshidvard, Nastihan, Pilsom and Golbad. Such as Piran, he attended in the most Iranian and Turan's war and played a main role in these wars. Human is a good - Seeker Figure in shahname. He was killed by bijan. And Human's death, turan's troop is ruined (Shahname jul mol, 1995. vol. 2, verses 309-8628).

\section{CONCLUSIONS}

1. Tur family as the opposite side of Iraj Famiy (Iranian in shahname, are Fereidun's child /son. two family are Irani the difference / distinction between these two family is the way is adapted by Iraj and Tur.

2. Ferdowsi sometimes call Turan as turk to protest the rulings government Ghaznavid government who is stranger with Iranian culture and so, his precious literary work was not accepted by Ghaznavid king .

3. As we know Ferdaowsi was not sycophant poet. When the eulogy had great popularity, he deal deals with epic. He likes all the heros of shahname and has a proportional view regarding his heroes. Although he describes Tur family in bad side, he introduce Iranian as proportional figures. Such that some time he thinks some Turan member, such as Piran and Human and even Afrasyab, in some aspects characteristics are better than Iranians.

4. In describing the reality the world is the war-place of oppositions, Iran and Turan, Afrasyab and Kaixosro, pain and treasure, good and bad, are considered as the components of it. 
5. Ferdowsi, based on proportional tendency regarding good and bad thoughts, can solve the opposition between mythological faith in believing into the options / free will as a main component of his sectarian thoughts.

\section{References}

[1] Eslami Nadushan, Mohammad Ali (1970). "Life and Death of heros in shahname", Second edition, Tehran, Ebn Sina Press.

[2] Fersowsi, Abulghasen (1995). Shahname (Mocqo press) by Saaid Hamidian, first edition, Tehran, Dad Press.

[3] Fersowsi, Abulghasen (1991). Shahname, edited by jul Mol, fifth edition, Tehranm, Islamic Revolution Education and Press.

[4] Gharib, Mahdi. (1990). Shahname Review, Tehran, First edition Tuss Press.

[5] Kuruji Kuyaji, Jahangir (1992). Researchs in Shaname, jalil Dust khag; Report and Edition, First edition, Zende Rud Press.

[6] Mosahab, Gholamhosin (1953-1960). Encyclopaedia, Vol.1, Franklin Press, Tehran, New YORK.

[7] Pour Davoud, Ebrahim (1988). "Yashtha", Second edition, Tehran, Tahuri Library Press, Iran Culture and Language.

[8] Rastegar Fasai, Mansour (1991). Shahname's names Bibliography, first edition, Tehran, Cultural Studies Press.

[9] Razmjoo, Hosin (1989). "Ideal Human in Epic and Persian Mystical", first edition, Tehran, Amir Kabir Press.

[10] Safa, Zabiholah (1990). "Epic in Iran" fifth edition, Tehran, Bahman Press.

[11] Saif, Ali Mohamad (1991). "Passing through Shahname", Tehran Bahman Press.

[12] Sarami, Ghadamali (1994). "From the Flower color till Thorne Pain", Second edition, Tehran, Scientific and Cultural Press.

[13] Zanjani, Mahmood (1993). "Shahname Comprehensive Bibliography", first edition, Tehran, Ataee Press. 